\title{
3 \\ One of the Most Persistent Bitches: Judy
}

I was about one and a half when, in 1946, I was put in the Queen Alexandra Home and my sister Gloria must have been about seven and my other sister Beverly was nearly four. My brother was born just after that. I was the first one put in the institution. I lived there until I was 12 years old. My mum had walked out on us-her four children-and dad served in Japan during the war. He sent money to the Home, about 14 shillings a week, for the whole family.

\section{Queen Alexandra Home}

My first memory-me sitting in a cot with my foot all bandaged up because I had stepped on a nail. I remember it being so funny, me throwing my food at other girls. There was a Mr and Mrs R. there. They wanted to adopt me and my dad wouldn't sign the paperwork. I can remember my sister Beverly and there were people we used to call 'Matron' and 'Sir'. My brother was never put in there. He was adopted out to other people.

Queen Alexandra Home was a huge building full of tiny children. There were private wards and state ward children. Still to this day I can remember the front entrance and the black and white tiles. I can't walk into a house that's got black and white tiles. I have to get out of it. There must have been 100 children in there. Sir and Matron were pretty brutal to us. There was a bottom dormitory and there was a dormitory upstairs when the girls got a bit older and there was a small boys' dormitory at the top of the stairs next to the Matron's and Sir's quarters. When they reached a certain 
age, they were sent out of the Home and put into another institution. One of our aunties worked there. There was probably about seven or eight staff altogether, including a cook, a gardener and the guy that chopped the wood up for the big wooden stoves in the kitchen. My father wasn't allowed to visit me at the Home.

There was just no compassion shown to us. The beatings we got were absolutely shocking. They had this thin piece of bamboo and they used to take your pants down and whack you with that or there was the strap that they used to sharpen the razor and they'd belt you with that. I was only little and they'd belt you with these sort of things. It affected me because they would - and I think that this is psychological cruelty-make us line up and we used to stand for sometimes two hours, waiting to be belted.

Can you imagine what that does to a child, the waiting and the thinking, 'How bad is it going to be this time? How many belts am I going to get?' And for absolutely nothing. Just nothing. They were so sadistic, these people. They seemed to get their jollies by being cruel to children.

A 'Mr Q.' came there and he was a dirty old bird. They had baths up on the big old concrete blocks and we used to climb up on the concrete blocks and had to put our little legs up over to get into the bath and the gardener used to stand at the louvres and look through the windows and $\mathrm{Mr}$ Q. used to come in to bath us and he made a point of watching us between the legs and we'd have to get out and he used to stand there and watch us. I reckon he was just a dirty old bird. They were very cruel in there. They were very cruel.

On the street, there used to be a stand where you'd buy newspapers. We used to up-end it and take the money out so that we could buy lollies. We'd have to go to church every Sunday morning in Coorparoo and we'd walk past this beautiful big mulberry tree and, of course, mulberries - we never got fruit or anything like that and the owners of the tree would give us a punnet of mulberries and say, 'Here's a shilling, go get some ice cream.' And of course we'd go Home and they'd say, 'Have you been eating mulberries?' And we'd say, 'No.' But our mouths were purple and so we got the shit belted out of us. For what? And it was the constant hunger. The porridge in the morning would be full of weevils. I am lactose intolerant and they would make me drink milk. I couldn't stomach it and they would make me vomit it up into the glass and re-drink it every time I vomited it up. And to this day I can't touch anything with milk-custard, anything. 


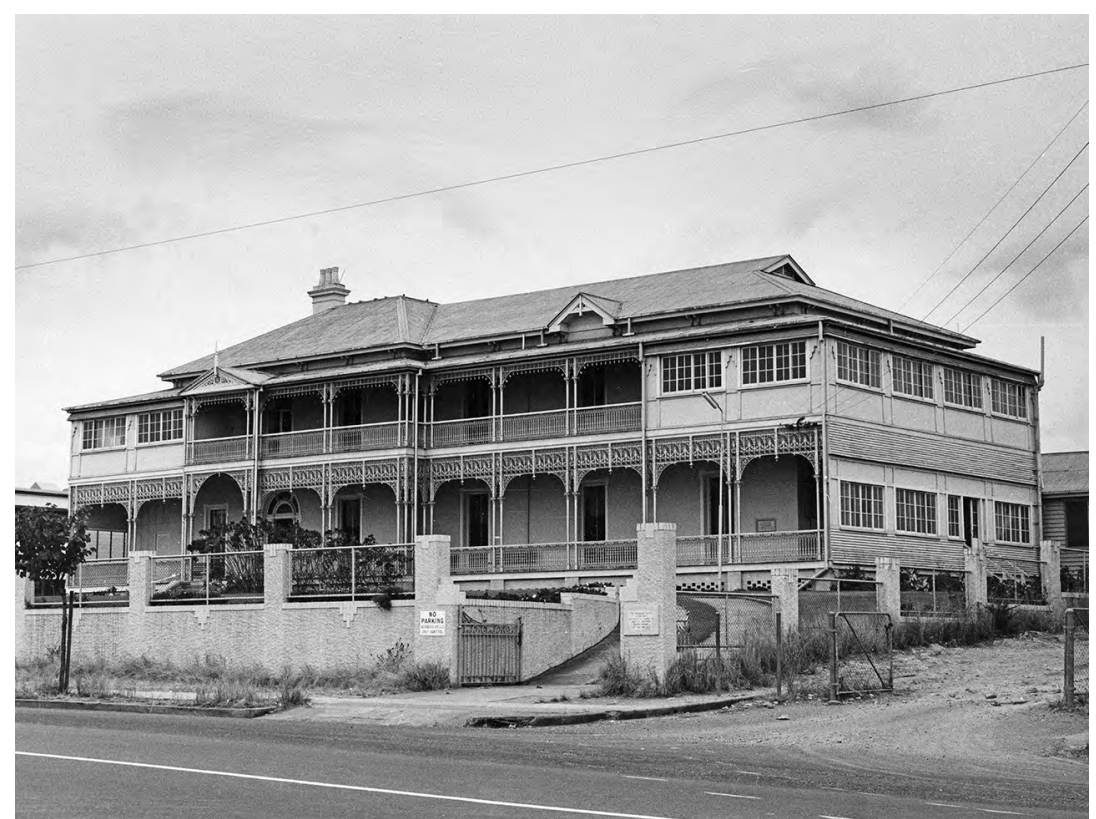

Figure 2: Queen Alexandra Home, Old Cleveland Road, Coorparoo, Brisbane, c. 1950.

Source: State Library of Queensland.

We were always so hungry. In the morning before school we used to go into the cake shop and they knew we were Home kids and they'd give us the old cakes because they knew were we hungry. We'd bring them back and we'd hide them underneath bushes and we'd tell the tiny, little kids where to go and get the cakes.

The Coorparoo State School was right next door to us. We were always called the 'Homies' and that has stuck with me all my life. We were always differentiated. We were below everybody else and the teachers never bothered try to explain something if you didn't know it. No one cared. You either knew it or not. We virtually never got an education. When my sisters reached a certain age, they were taken out of the Home and put in Wooloowin and were told that because Beverly and I played up that Gloria was going to be put in a lion's den. Now you don't go and tell that to two little children. That's just horrific and I never saw my brother. 


\section{Foster 'Care'}

We were going to Mrs S.'s every weekend. She lived at Yeronga and was a committee member of the Methodist Church. In the end she asked if she could foster both Beverly and I. Beverly never liked her because she was so cruel and Beverly was terrified of storms. She would make Beverly stand outside in that storm and Beverly just up and ran away. So I was there on my own.

Mrs S. was a religious freak. That's why I'm not religious. I don't think that we were any more than slaves for her to do the work that she couldn't be bothered doing. When I was 12 I was handed a push mower, mowing this huge property that she lived on. In those days, they only had boilers with big wooden pegs. I was a little girl and I used to have to lift that stuff out of that boiler and put it into cold water. Then I would have to put it through a hand wringer that I could hardly move and then put it out on a line and they had big wooden sticks to lift it up. I would then have to bring that in and do all the washing up. I had to do the work around the house. That's all we were-slaves. If I did something wrong, I would be locked in that bedroom. I wouldn't get a skerrick of food. I would have to walk to school—no lunch, nothing — and then walk home from school of an afternoon and I'd be locked in that bedroom without any food or anything. That woman used to thrash the living lights out of me. Mrs S. was a brutal woman. I don't know why they had to be so brutal. She used to get absolute pleasure by belting me. She'd make a cake and it would go mouldy and she'd cut the mildew off the cake and I would have to eat that. I can remember so bloody much. None of these people from the institutions realise that we have got such bloody good memories-'never forget'.

She had a boyfriend and I would come home and I would find them behind the door, fooling around with each other and I just used to get the shock of my life because I'd never seen anything like that in my life. I was a very naive little girl.

My dad would come to Mrs S.'s and he was so drunk that she just told him to get out of the house and then he came to the school one time. They rang the police and took him away. I had constantly been told that my dad was a dirty old man and that he didn't really want us. They made me terrified of him. 
While I was at Mrs S.'s she went down to St Mary's in Sydney for a holiday with her boyfriend and left me with the bloke over the road, Mr L., who molested me every opportunity he got. She must have known what he was doing. At that age, all I knew was the institution. It was something that you never said anything about in those days. If you told anybody that someone was molesting you, they'd beat the living shit out of you. You just didn't talk about things like that. On a Tuesday night we used to go to the movies and Mrs L. used to put bright red lipstick on me and rouge on my cheeks and she used to put little heels on me. It was as though she was grooming me for him. I went to the police station at Inala a year ago and told the policewoman about the sexual abuse and they investigated it. They found out his name but he died when he was 91 years of age and so there is nothing that can be done.

I ran away from Mrs S.'s in the dress I was in. No shoes. Nothing. At the time I was working. They got me a job in a book depository. Now I never had an education. Why give me a job in a book depository where I had to deal with paperwork and that sort of thing? I had no education.

All the time they'd threaten, 'If you lose your job, lose your job, lose your job, we're going to put you in another institution.' I was terrified of going to another institution. I was also a nurse's aide at an old people's hospital. I used to really enjoy it. In my files it says that I was asked to leave because I became 'too rambunctious'. That's an out-and-out lie. I left the hospital because I got a job at another hospital. I wasn't over the top. I was a shy little girl. Mind you, I'm bloody well not shy now! But my hospital work stopped when I ran away from Mrs S.

\section{Absconding}

I got on a bus and I ran away to my friend Helen's. She went to the same school as me. I went to her house and stayed there for about three nights. Her dad said, 'She can't stop here any longer.' So Helen said, 'Look, I'm going to have to take you to Stones Corner. You should be all right there. You'll meet somebody there who'll help you. You'll be all right.' Stones Corner was a suburb where the bodgies and widgies used to hang around. Helen was a bit of a widgie and her brother was a bodgie. He had a motorbike. 
But I'd lived a sheltered life. I didn't know what to do. I was hanging around Stones Corner and I sat at a bus stop and it was right near a car yard and I tried the car doors and got into one of the cars and slept in the back of that, that night in the car. The next morning-I was used to getting up and washing my face and that sort of thing-I went down to a toilet and this bloke was standing there and he said, 'What are you doing?' I said, 'I'm going to wash my face'. He said, 'Well come into the men's toilet and if you need some money, I'll give you some.' And me being so naive went in there! Some people had seen it happen and rang the police. The police come and said, 'What are you doing here?' I said, 'He told me he was going to give me some money.' They said, 'We think you better come with us.' They told me they were going to take me back to Mrs S. I said, 'No! I don't want to go there!'

\section{Kalimna}

I thought my sister was at the Salvation Army and so I said to the police, 'Will you take me to the Salvation Army please?' So they took me to the Salvation Army to Kalimna at Toowong. In my paperwork it says while I was at Stones Corner that I was promiscuous. I didn't even know what the word 'promiscuous' meant. They took me in, early in the morning, and I was put in a cage. They let you out to go to the toilet. There was a Matron. there who was also the local member in government. Dr C. was the doctor who came in. When you were taken to Kalimna, you were physically examined. They didn't tell you what they were going to do. He put your legs up and he put one of those things inside. I'd never had anything like that done to me in life, apart from that bloody bastard who lived opposite Mrs S. $\mathrm{Dr} \mathrm{C}$. was just so brutal. It was as though they did everything in their power to hurt us young girls. No need for it. Afterwards, I bled for 10 days solid. What right did they have to do that to a young girl?

Matron wrote in my records that I ran around the dormitory at night and kept the girls awake. I was never admitted to the dormitory! I can't believe these Christian people could tell so many blatant lies! I was let out of that room twice. Once I went in to have breakfast and I can even remember where I sat. There was tables and chairs all around the room. There was a stage and I sat at the end at the left, and then another time I was taken down to the rec room where the girls used to sit and I was down there for 
half an hour and they put me straight back into the room. In my files it says that I was talking in a smiling way about committing suicide. I would never commit suicide!

I was locked up all the time. I was 15 . After the cage they put me downstairs. If you were 'uncontrollable', they put you down in the isolation ward where there were six cells. They were all staggered so that we couldn't see or talk to each other and it was called 'POP' (place of punishment). There was a mattress on the floor and we had no toilet. They would take us for a shower in the morning, breakfast in the room, if you could call it breakfast. We'd be let out to go to the toilet three times a day and when the sun went down we had no lights in the room and that's where I stayed the whole time. I just lay on the mattress. Do you know how agonising that is to the soul of a child? It's just cruelty, out-and-out cruelty to children who had done nothing wrong, absconded from something they didn't like. I'd been sexually abused by the neighbour of the foster woman and I was angry about that. They said I was running around dormitories at night. I never went near them! There were also girls who were up in dormitories. I got out twice-once to have breakfast one morning in the red room. It was a long table and the girls sat on forms at the table.

You could yell out to each other but they'd tell you to 'shut up' or give you more drugs to shut you up. It was just hopeless. You were drugged up the whole time. These people were supposed to be religious. Matron was a liar. I can't stand liars. I think this is why I'm so outspoken because I don't believe in lying. Whatever I say is the goddam truth all the way through and I do not suffer idiots. I don't care. I've got to the stage of not worrying what people think. 
GOODNA GIRLS

Salvation Army promotional brochure Kalimna: Lovely Home (1963)
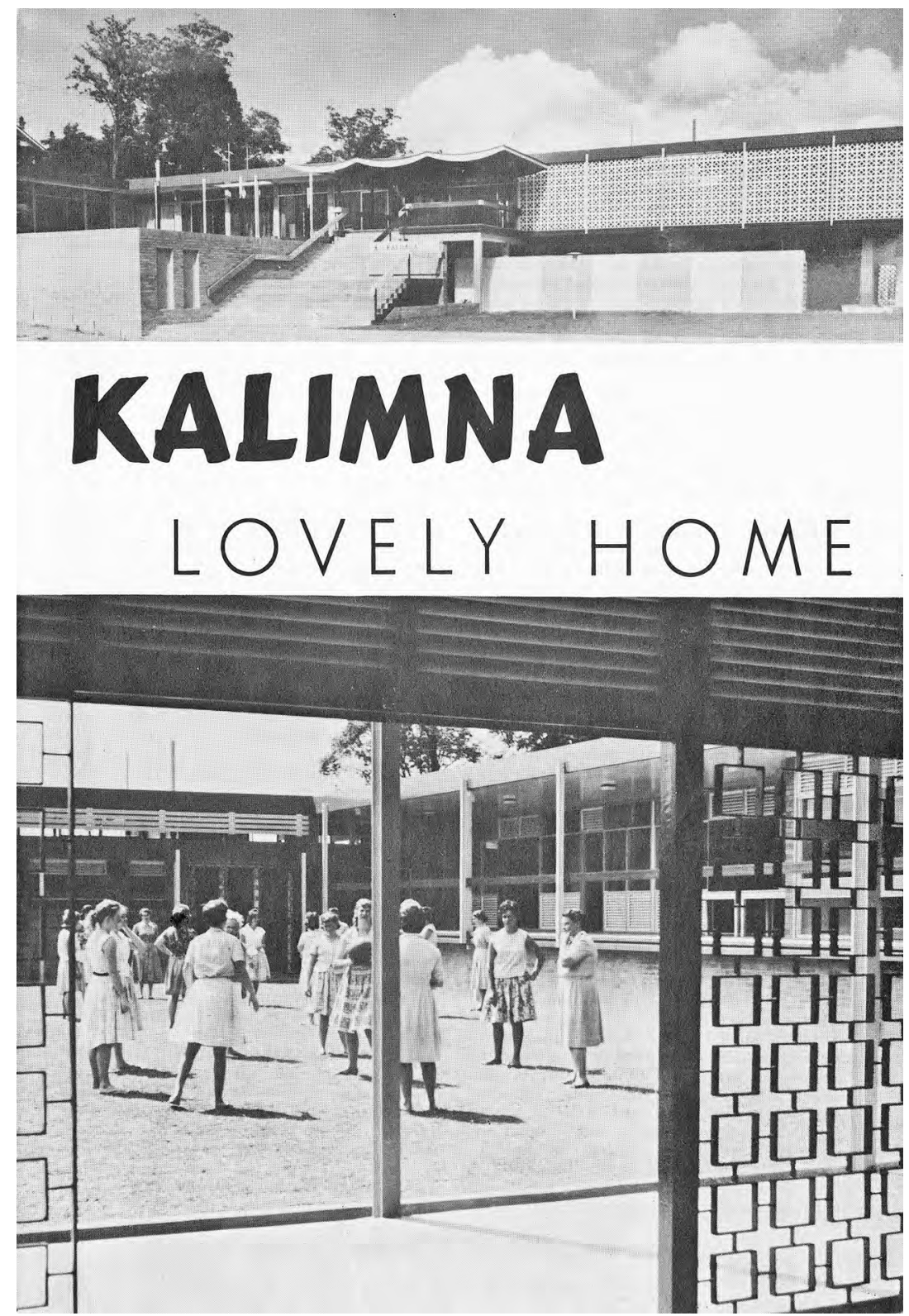


\section{KALIMNA-}

\author{
A \\ TEXAN was once endeavouring to \\ impress a Queenslander with the \\ size of his State. 'We have trains \\ and all night and still be in Texas.' \\ 'I understand,' said the Queenslander \\ sadly. 'We have trains like that as well.' \\ Leaving aside considerations of public trans- \\ port, the fact is that if you double the size of \\ Texas and then add New Mexico or Montana \\ for good measure, Queensland will still be \\ larger. \\ Or if transatlantic measurements leave any \\ old-world reader cold, then add Western Ger- \\ many to France, to Italy, to Spain and to \\ Portugal, and the resultant area reaching from \\ Hamburg to Cadiz and from Bayonne to \\ Brindisi will still be slightly less than Queens- \\ land. \\ Now place a pin point in the south-eastern \\ corner of this immense area. Let this represent \\ the one and only Protestant home for delinquent \\ girls in the whole of the State, and some smal \\ idea will be gained of the sphere of operations \\ of 'Kalimna' - an aboriginal name which \\ means 'lovely home'. \\ The work of The Salvation Army for girls in \\ Queensland, and particularly in the state \\ capital of Brisbane, goes back to 1886 . A \\ domestic house in the inner district of Padding- \\ ton was the scene of modest beginnings, and a \\ year later the work was transferred to larger \\ premises in the nearby suburb of Milton.
}

\section{GOVERNMENT GENEROSITY}

In 1896 a more commodious dwelling was secured on the outskirts of the city at Taringa, but early in IgI4 this was burned down. Then followed the purchase of a timber house at Toowong, and this old building-adapted and altered and readapted and realtered - served the purposes of this redemptive work until last year when 'Kalimna' was built at a cost of fi 140,000 , the State government generously meeting 75 per cent of the capital cost.

As the pictures will show, nothing less like an institution could be conceived. A broad stairway from a quiet street leads up to an inviting doorway at which the Matron, Major Jean Geddes, awaits any interested visitors who may call. The flow began even before the Home was officially opened-students taking a social service course at the university, the Mother Provincial from Melbourne, welfare workers from the United States, officials from other State children's departments, government repre- sentatives from Colombo specializing in work with sub-normal children in Ceylon. And well they might come, for General Kitching observed on his own visit this year that he had seen only one other building of its kind in the whole world to approach it.

But behind the pastel shades and delicately tinted drapes there is a passion to redeem the cirls who are in residence, all of whom are between fourteen and eighteen years of age and have been committed to the Army's care by the children's courts. All have been, or were, in danger of being involved morally. The means for their cure is expressed in the lay-out of the building itself, as will be seen as the Matron takes visitors around.

\section{LOOKS BELIE}

By the way, let no one suppose that the Matron's lack of inches indicates any lack of capacity to deal with any emergency which may arise. Said one distinguished visitor at the opening of the Home in November last: 'I expected to see a tall commanding lady.' What counts in Matron Geddes is measured from the shoulders upward. Twenty-five years of experience with human nature lie behind those friendly eyes - as more than one turbulent girl has discovered on arriving at the intake suite which lies to one side of a pleasant and roomy grassed courtyard.

\section{CHALK PROVIDED}

'Suite' is perhaps the only word which adequately describes this self-contained unit with all modern conveniences which can house five girls. Fastened to each bedroom wall is a small blackboard. Chalk is provided below. The temptation to inscribe graffiti on the walls magically vanishes when the means to write on an appropriate part of the wall is provided. Morning light has been known to reveal a list of boys' names chalked on the blackboard, or at other times a prayer: ' O God, let me go home on Friday.' But the desire to go home diminishes as the new girl realizes the delights of her present home.

Along the courtyard from the intake suite lie the craft rooms - the sewing-room, the commercial room, the beautician's room. Under expert tuition the girls learn to make their own dresses. To be taught typewriting without expense is a chance which does not come every teenager's way. And, as every girl wants to look her best, the visiting beautician teaches deportment and dress sense. 
At right angles to the craft rooms and flanking the far side of the courtyard is the gymnasium. Showers are conveniently adjacent, and again both body and mind benefit from skilled training. Full marks should be given to the voluntary experts who freely visit the Home in their spare time.

\section{PRIDE IN SURROUNDINGS}

The middle section of the Home takes twentyfour girls, and it is to this series of three-bedded rooms that the newcomer is transferred in due course. Each girl has her own built-in wardrobe and set of drawers. Each bed has its own bed lamp, and the delight and comfort of these rooms are such that a girl begins to take prid and pleasure in her new surroundings. This is reflected in the care which she bestows upon her room and its contents, for each girl knows that misconduct could mean relegation to the intake section once more.

The final stage is when a girl is promoted to one of the twelve single rooms in the hostel section. From here, if necessary, she can go out to work during the day and in the evening return-not to her old neighbourhood where the odds were weighted against her, but to the unforced, unsanctimonious care of the officers who have shown her such affection and for whom she has conceived a genuine affection in response. For many of these girls this place stands for their first experience of being loved for their own sake and of being able to return that love without fear of the consequences.

Of course, behind the seemingly effortless running of this attractive Home for sixty-three girls lies an immense amount of work. The Matron can be called upon by the State chil dren's department, by the police, by distraught parents - and by the girls themselves at any moment of the day. The resident officers live not for themselves but for these delinquent teenagers. They both share and supervise in the laundry where the girls work in order to help to meet the bread and butter expenses of the Home.

'Kalimna' could not live up to the meaning of its name without the Christian faithaccepted not as an arid dogma but as the presence of a living Lord.
Sunday mornings see the girls sharing in the holiness meeting at the nearby Toowong corps. Family prayers are held each day in a pleasan meeting hall whose glassed wall overlooks the entrance steps. Here stands the Army flagthe only visible religious symbol-with its significant colours.

The assembly hall also provides a meeting place for an evening's entertainment. At the movement of a shutter a cunningly concealed canteen opens its inviting counter. Here tea can be served and here also can be purchased the knick-knackery dear to a girl's heart, for each has a credit standing to her name through marks gained for good conduct and good work.

But the severest discipline of all is for a girl to be forbidden the swimming-pool. In a city where the average annual temperature-that is, taking winter as well as summer-is 60 degrees and the average maximum is 78 degrees, a swimming-pool is as much a necessity as a luxury. Tantrums rapidly abate when the penalty is known to be-no swimming.

\section{FRANK QUESTIONS}

It might be said that this short description gives too rosy a picture of life at 'Kalimna' Each girl has her individual problem and most often she is her own biggest problem. With these girls their stay in the Home often constitutes their first contact with folk possessing a genuine personal Christian experience. Much of their past life has wrongly taught them to be wary of religion. Do-gooders are regarded cagily. But before long they realize that the richness and variety of life which they have been seeking at such dubious sources and in such questionable ways is spontaneously present in the lives of the young women officers who live with them from dawn to dusk. Frank questions are asked and frank replies are given. A dawning appreciation of the Christian faith is awakened in the hearts of these young girls through the blessed infection of the lives of those who themselves radiate the beauty of Jesus.

About this service three things may be said. It is unspectacular and, by its very nature, cannot be publicized in detail. It is - in the phrase of von Hügel-costing. But its effects are lasting. Here is fruit that abides.

\title{
A SALVATION ARMY SOCIAL SERVICE
}

\author{
(Reprinted from "ALL THE WORLD," July-Sept., 1963)
}




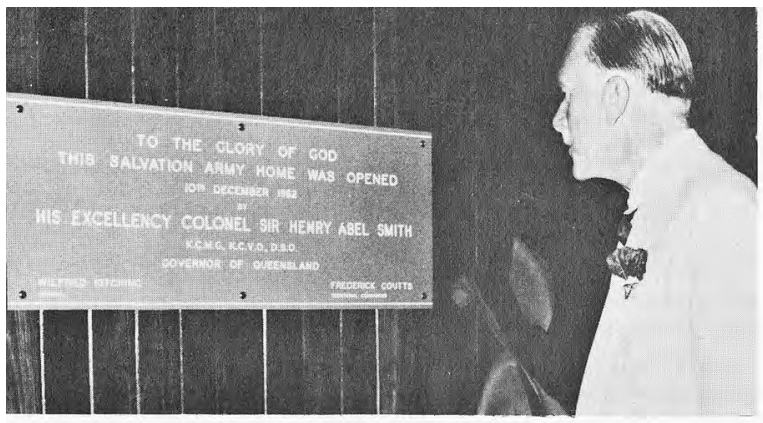

Left: The Governor of Queensland, Sir Henry Able Smith, who opened the home, unveils the commemorative plaque at the entrance of "Kalimna."

This beautiful property in Queensland provides the new environment for the Army's work for delinquent girls, which is described overleaf by General Frederick Coutts and which began as long ago as 1886 .
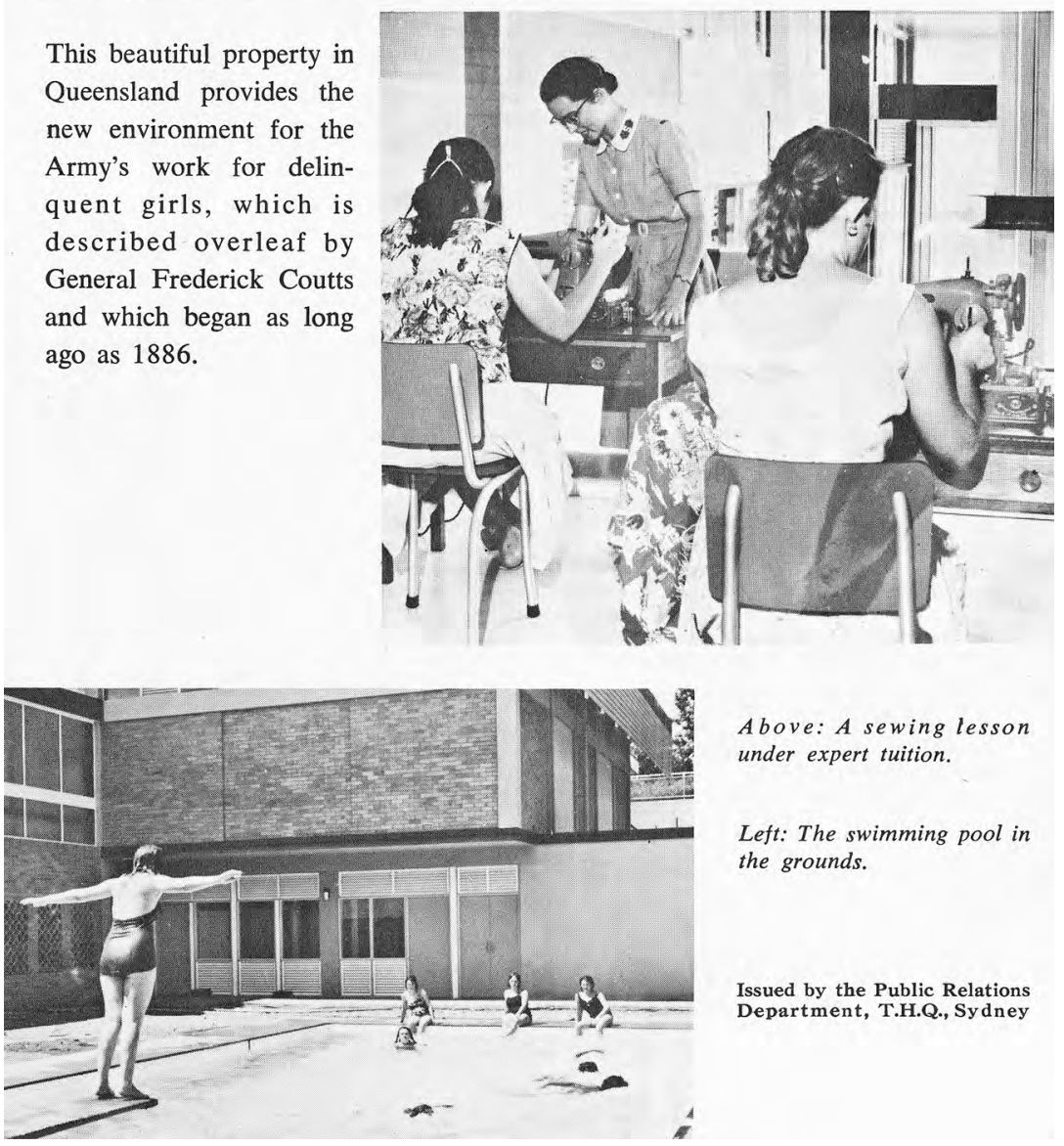

Above: A sewing lesson under expert tuition.

Left: The swimming pool in the grounds.

Issued by the Public Relations Department, T.H.Q., Sydney 


\section{Lowson House}

Then all of a sudden, they just came down and got me and they put me into Lowson House in the Brisbane Hospital and I stayed there for 10 days and then they put me into this big cage-Ward 16-which was full of people that were really mentally deranged. I can remember sitting in a corner on my own. They never told you a thing. No explanation. Not a thing. There were about 20 patients in there and mattresses. I can remember sitting in a corner on the floor for hours on end being terrified out of my life because these people were severely mentally impaired. I was absolutely terrified. They were mental. They were screaming and yelling. They were being violent towards each other. I'd never seen anything like that. The way these people carried on. Now I look back on it, they were more to be pitied.

Nobody came near us. I think I saw my caseworker, Miss S., once. She came and saw me once. It was very flippant. She'd say, 'Are you coping?' There was no inquiry into what was going on.

\section{Goodna}

I was in Ward 16 at Lowson House for about three days and then they just took me. They came and got me and I didn't know where we were going. I had no idea. They took me out to Wolston Park. They called it 'Goodna' then-Goodna mental hospital. They took me into the Barrett Centre. Dr Barrett was in charge. Everyone knew what Goodna was. At school we'd talk about it. All the nutters lived out there but I never thought I was going to go up there.

I was first taken into the admission ward. Now for some strange reason they kept me in the admission ward for six months because I think they realised that I wasn't mental. There was absolutely nothing wrong with me. I retaliated at being constantly institutionalised. That's all that ever happened to me. I was placed in institutions. I was nothing. I was a little girl. I hadn't done anything wrong. I hadn't committed any criminal acts. I wouldn't put up with crap. I think that I've always been like that but not so much as I am now. 
I'd see them hurting patients and I would say, 'Why are you doing that?' In the middle of winter, I saw them put old women in icy cold baths and they had these big wooden boards over the top and locked down on the baths and all they'd have was their heads sticking out and these old people would cry, 'Please help me. Please help me.' We couldn't help them. What could we do?

There was one elderly woman. I thought she was old. I don't know how old she was and they picked her up by the hair and her hair came out. And there was blood running all down her face and they were kicking her and punching her. And I actually broke down. I can always remember that. And they put me in isolation because I got upset at what they were doing to this elderly woman. She'd done nothing.

I think that we-for all our abuse-were compassionate towards other children and other people who were abused. We spoke up for them-us girls who were out at Wolston Park. We tended to stick up for people who we thought were being mistreated. At Queen Alexandra Home, as we got older, we used to defend the little ones. We'd take them under our wings. Even aged 10. I used to think I was a big girl at 10 but I was still only a child myself, but we would try and protect the little ones. If we used to see someone picking on the little ones. My sister used to do that for me.

I think I was put in Goodna because I wouldn't conform to what they wanted me to be. I think I've always been a very determined person. I don't like unfairness to people. I can't stand people being unfair. If I see somebody picking on somebody, I have a go at them. I say, 'Do you enjoy what you're doing?' I've got to the stage where I don't care anymore if people think I'm not a nice person. I've been told, 'Someone's going to hit you in the gob one day.' And I say, 'Yeah, but they'll leave that person alone, won't they?' I've become like this.

I wasn't badly treated when I was in admissions at Goodna. We just used to sit out on the front verandah and you could see cars and people walking along the road. There were still big wire fences around admissions. I couldn't come and go as I liked but I thought, 'Oh this is good. At least I'm not locked up in a bloody room all day and fed drugs.' I could walk out to the front and sit out there and watch the cars go past.

Then, out of the blue, they took me through this gate and they had these big keys and they unlocked the door and they put me in this end ward. I didn't have as much freedom. I'd say there were six or seven young girls 
in there at the time aged between 11 and 15 and we could sit and talk. We'd say, 'What Homes have you been in? How come you're in here?' Most of the girls had absconded from Homes. The only place I absconded from was Mrs S.'s. I was in that ward for about 18 months. I was 16.

I had told one of the nurses, 'I'm thinking of running away.' She had said to me, 'If you ever get out of here, come and visit me. I'll look after you and cover for you.' She gave me her address and told me to keep it hidden.

Then some tradesmen came in and left tools behind and so I took a screwdriver and I undid the screws on the wire on the windows and another girl and I escaped. When I ran away, I got out to Ipswich Road, hitched a ride and went to the nurse's place. She got me a live-in job with these two women who used to go out each night working. I used to clean their house and look after their kids. I found out later that they were prostitutes. There was this bloke who would come and visit the house. The nurse introduced me to him. He was about 18. He paid me attention. Anyone who paid me attention seemed nice to me because I wasn't used to anyone caring or taking notice of me. I just soaked it up. I started going with him. I also got in contact again with my friend Helen. This bloke I was with had a motorbike and he took me over to her place. Her brother had a motorbike too. I'd never been on a motorbike in my bloody life. So we all ended up going for a ride. We went down this street at night. The blokes didn't realise it was one-way and they hit the end all of a sudden. The bike fell over and landed on my leg. I got up and couldn't walk. They took me to the Brisbane Hospital but they didn't do anything-just gave me a pair of crutches. The bloke I was with took me back to his place and I was in so much agony. I went back to the hospital the next day and this time they put plaster on my leg. That bloke had been going out with one of the women in the house but he left her to go with me. She was jealous so she dobbed me into the police for breaking out of Goodna. So the police come and got me. I had been out of Goodna for a couple of months.

This time they sent me to Ward 8 with the criminally insane. There were mostly adults in there. They were poor buggers but it was also called 'J. D. Ward'-juvenile delinquent ward. There were only about four or five of us girls in there. There was a big garden out the front where you'd have your visitors, if you ever did have a visitor. At the back there was a big cagedin area with chairs that they would tie us to. And there was a part up the end where they would put the really severely mental patients where they 
were tied down to the chairs and they would piss and they would crap just where they sat. On your left there was a dispensary and then there was the big dining room and there were very narrow windows that you could see out the front. Right to the back of the dining area there was the kitchen. There were about five girls' rooms and there was a dormitory opposite the single rooms and up the end was the bathroom. At the end where I slept, you could see out onto the verandah and they would come and bolt the shutters up every night and lock you in the room and you were in the pitch black. I can always remember a young girl named Andrea and another called Carolyn.

In Ward 8, I told the nurses that I was very itchy and having discharge. They put me up into the hospital part. That bloke had given me venereal disease. I didn't know anything about it until then but there I was in hospital with gonorrhoea and my leg in plaster. I can remember them sticking needles into me and taking me backwards and forwards to the general hospital. I was ostracised because I had venereal disease. I haven't had it since, but in those days, if you had it, you were a dirty, dirty person. It was there that I reckon that they gave me shock treatment because I know all about it. How do I know all about shock treatment? How do I know the room where they did it? It was in a red building across from Ward 8. I knew how they strapped you down and tied your legs up with leather straps, how they put things in your bloody mouth and held you down. How did I know all that? I don't remember them doing it but when I was let out I tried to put it all behind me, but when they brought it all out in the Forde Inquiry all these things came back to me. For the inquiry we had to write over and over and over and over again about what had happened to us. I don't think that was fair. I think we should just have been able to say to somebody once what happened. We just had to tell it over and over again. I got on with my life and tried to put all of this behind me but they brought it up in 1998. Brought the whole lot up again. Brought the most horrible pain back. I had got on with my life. I travelled. I nursed. I went to New Zealand. I lived in England. And then I came back here and I had my son and I got on with my life. We women from Goodna find it very hard to show love to people, to our own children.

At Goodna, we got given drugs every morning, every noon and every night. They'd give you Largactil and on a regular basis you'd get Melleril. You look up the side effects. It was like Valium to keep you quiet. When we were given Paraldehyde, they would strip us naked and put 
a straightjacket on us and we would have our head pulled back and they'd stick the needle into the muscle of your leg and they were supposed to put it in very, very slowly but they just used to push it in our legs and you can still feel the pain of it. Once I say 'Paraldehyde', I can taste it in my mouth still. It would come out your body the next day. You'd constantly have the smell of Paraldehyde. It was white, thick stuff and absolutely agonising.

And my god - the abuse, the abuse! These dirty old bastards. These bloody men. They would call the male warders over to hold us girls down while they injected drugs into us. I'm sure these people went home to their family at night to their wives and children and I'm sure they went to church on Sunday morning and were told what good people they were, but in the meantime, they were molesting these little girls, raping little girls. They just did what they liked to us. I was under the age of consent. They had no right to touch me-filthy bastards. The trouble was, we were in such a zombie state from all the drugs, we couldn't remember who these people were.

And then you'd have the showers that had no doors on them, and the toilets had no doors on them and they would stand there and at that age you are so embarrassed. You are just starting to mature. You don't need dirty old bastards like that talking about you. The male warders would say, 'Look at your little titties. Look at your little pussy.' It was so embarrassing. You didn't only have to contend with them but also with the patients. I can picture that bloody woman at this table. There were four chairs. I sat on one chair and there was somebody on my right, somebody opposite and the chair on the left was vacant. Well, she would stand up on the chair and would jump across that table and batter the living shit out of me and they wouldn't move me. I said, 'Will you please move me?' They thought it was funny.

They said I would put on an act because I couldn't get a light for a cigarette. I never smoked! And where was I going to buy cigarettes? The nurses locked us in single rooms at night to protect us from the mental patients. Someone told me there was a woman in there who had slashed her children to death with a machete. Why would you put a child in with people like that?

The nurses would stir the patients up to bash us up. If you wanted to go to the toilet you'd just wee in the corner. And straightjackets? I think I lived in a straightjacket. And when they put the straightjacket on you, they 
would tie you down to these big canvas chairs and if you wanted to go to the toilet, you just wee'd there, and some staff would stir the patients up to bash into us. The so-called nurses, doing their training, weren't nurses' bum holes. I don't think one of them had a day's nursing experience in their bloody life. They were only young girls that would come in and apply for jobs at the hospital. They'd have a sister in charge but mostly only very young girls.

I miscarried twice in my twenties. The doctor asked if I had tried to have an abortion because the baby that I lost, when I was six months pregnant, was so badly mangled up. I put that down to the drugs that were injected into me when I was younger-Largactil, Melleril, Paraldehyde.

I was in Ward 8 until I was 18. Altogether I was in Wolston Park for three years. When I turned 18, my dad knew that I was no longer legally under state care. My dad found out where I was and sent my two sisters to come and get me. We sat out in the garden and they said that they didn't know I was in here. Dad wasn't allowed in Queensland because he owed money for us being in institutions. The State Children's Department wouldn't let him come near me.

My sister gave me a gold crucifix on a gold chain when they had come up to see me. The nurses ripped the cross and chain off me-just ripped it into bloody pieces. They stirred up a young girl to come and bash me. That was precious. I never had anything nice in my life. And to get that chain from my sister was absolutely precious because it was mine! And they made a point of ripping this chain and crucifix off my neck and bash me up because I was leaving and they said, 'Oh she's going out next week.' The trouble is the girls had been told that they would never get out of there alive. I believe Carolyn is still in there. When my sisters visited me again, they asked me where my crucifix was and I told them what happened to me. I got out of Wolston Park two weeks after them coming up to visit.

\section{Sydney}

The woman from the Children's Department came and got me out of Wolston Park, took me into shops in the city, bought me some clothes because I had nothing. I had no shoes-nothing. I virtually walked out of Wolston Park with absolutely nothing. You never owned anything. 
I'd never had a normal bra because the woman I was boarded with, Mrs S., used to make me wear flat things and little shoes and socks like a little child. She wouldn't let me grow up. But Miss S. bought me little training bras and a pair of brown desert boots and a blue dress.

Miss S. took me to the airport and I had to walk upstairs to get to the plane to Sydney. My two sisters picked me up from the airport down in Sydney. My sister Beverly had been in a Salvation Army Home in Queensland after leaving Queen Alexandra and she escaped and hitchhiked to Sydney to be with our other sister Gloria. But when Beverly got there, the police picked her up and put her in Parramatta Girls Home. I know she was sexually abused in there. The trouble was, they were now 'working girls'.

My father had brought my brother down to Sydney and they put us in a flat at McMahon's Point. I got a job at Randwick Private Hospital as a nurse's aide and I got sick to death of that, paying the fares from North Sydney over to Randwick every day. In the end my sisters told me not to bother doing it, that they'd support me and my brother. We used to go down to Luna Park every night and dance to the jukebox. My brother then disappeared off the scene.

My sister moved to Bondi and I moved with her and she got me doing the same as her in the end. We used to stand on the one corner at Kings Cross down William Street. We all had rooms to go to in Surry Hills where we worked from. We rented them from elderly women and that's how they got extra money. I never liked it. I had an aversion to people touching me. I did it for a few years until I fell pregnant with my son through what I did for a living.

My son's going through a really bad time at the moment and a friend asked me, 'Do you think it's come through your childhood?' And it made me start thinking. He's incapable of showing feelings to anybody the same as I was.

With my first pregnancy, I didn't even know that I was pregnant. I hadn't been out of Wolston Park long. I was living at Bondi and I wasn't working at the time. I was in a relationship with my eldest sister's boyfriend. I must have been 18 . She found out. We've never really been close since. He paid attention to me and I never had that before. I fell pregnant to him but miscarried. I was lying on a bed and my water broke and I didn't know what was going on. I'd never been told anything. I went to the toilet and I flushed it down and I didn't realise. 
Later these four blokes found out, through Beverly, about me being with my sister's boyfriend. She hung around with a lot of bad people. She's never had the smarts. These four blokes came to the house and one of them left because he knew what was going to happen. These were bad, bad criminals. They grabbed hold of me, pointed scissors at me and raped me. They hung me, naked, out of the window. The flat was on the tenth floor. The next morning Gloria took me to the police. They examined me and everything. I had to go to court over one of them. His solicitor brought up in court all about me being in Goodna. He came down hard on me. They even asked Dr B. from Goodna to go down to Sydney to give evidence against me. Before the hearing they had sent me to another psychiatrist because I'd been to Goodna. The psychiatrist said in his report that for all of what I was, I was a real prude and that I was only on the game as a means to an end, to be able to live. It was all in the paper about me being a prostitute. It was an embarrassing time for me.

But I had one of the jurors come up to me and shake my hand and say to me, 'You're a really strong girl, aren't you? You wouldn't take any rubbish off that solicitor!' That rapist got 15 years. The case against the other two came up later when I was in England so I couldn't testify against them.

\section{Travelling}

I ended back with my sister's boyfriend. We went to England together. I was 26. When we were living in Middlesex, I applied for a job as a nurse's aide but I wanted to do my training so I applied and went into preliminary training school two or three times a week but I was only on the wards. I did three months' geriatric, three months' paediatric, three months' surgical, three months' emergency. I became a registered nurse and worked at the hospital for four years but then I separated from the man I was with. I was pretty distraught and so my dad paid for me to come back from England. The man I was with was playing up on me when I was on night duty and got a very young girl pregnant and ended up marrying her. I didn't want to do the nursing anymore because I was just so traumatised by what that bloke had done to me. I wanted to leave England because I had nobody there for me anymore. I came back from England and I was staying with my sister Beverly at Maroubra in Sydney and I got a job in a factory making toothbrushes. There were a lot of Pommies working there and I just came back from England and I wanted 
to mix in more with English people but I was only being paid a pittance and I thought about going over to Western Australia. I went over to Hay Street in Sydney to a brothel and my sister Beverley said that she'd like to go to Western Australia with me. Well I couldn't say no to her and so she came with me. But I knew there'd be trouble. Beverley's always been trouble. Well it ended up to be true. She caught a disease and they threw her out of the brothel over there.

I bought a car over there so we drove back to Sydney. I had to pay all our way back to Sydney and she ended up with nothing. I'm known as a tight-arse and I'm quite happy about that. We drove back together and I got stuck on Parramatta Road. I was so angry because I'd never driven in traffic and Parramatta Road! My god! It was just unbelievable. Someone stopped to help me and saw that I had Western Australian number plates. They asked, 'Where did you come from?' I said, 'Out of my mother's cunt!' They helped me start the car and we drove back out to Maroubra.

\section{Back in Sydney}

I chose to move out and I heard about a unit through a friend of mine. I rented that and a girl named Gloria moved in with me. I got into a brothel at Kings Cross. There were too many wild parties in the flat where Gloria and I lived and the neighbours complained and so a heap of us went and lived in a big house in Neutral Bay. We all put in for the rent. That was a very exclusive suburb. I don't know how we got that house!

Then I went back to work because I needed the money and I fell pregnant through that. Nobody told me anything. Nobody told me about periods. Another bloke, who I was with, gave me money: 'Go and have an abortion.' I took the money and went out and bought baby clothes. I wanted a child. I wanted something that was mine. My dad was around at the time and he asked if I was going to adopt the baby. I said, 'No! I'm keeping the baby!' And my dad got the shits, y'know. It was my baby! I wasn't going to give it away. I had it done to me. I wasn't going to do it to a child of mine!

I was back on the game in Sydney even when I was pregnant. I know I shouldn't have done it but I did. I told the bloke I was with that he was the father, but he wasn't. I know that sounds terrible. Anyway, he kept me. He paid my rent and my food. I met him through being on the game. He always used to take me back to his place and he said that he'd prefer 
me not to work. He wanted me to just be for him exclusively and so I did it. It was worth it for me. He was a very wealthy businessman. I moved into a house in Bondi Road and Beverly moved in with her two kids and brought all her junkie friends with her, which made it very hard.

Beverly got on to heavy drugs. I should never have got Beverly involved in going on the game again. I really shouldn't have. You don't realise it at the time. I think she should have been there for her two children. They took her kids away because of the drugs. Whoever 'they' are- 'social workers' - came and took them. They asked me if I would take Beverly's kids. I said, 'How can I? I'm just about to have a baby!'

Beverly's children were fostered out and then Beverly got picked up by the police for having drugs. She got put in Long Bay Gaol and I asked this businessman to pay bail for my sister to get out of jail. He agreed as long as she paid him back. Well, she didn't pay him back and he got the shits and I told him politely where to fuck off. Beverly got her kids back after a few years. She hasn't had an easy life.

\section{Queensland}

Once I had Michael, when I was 27, I stopped everything and came and lived up in Queensland with my sister Gloria and didn't go back on the game. I had the baby and my dad said, 'I'm going to take you up to your older sister in Maroochydore.' I got a place right on the beachfront.

Michael was still a baby and I was on the single mother's pension. The owners, instead of me paying rent, said, 'If you clean the units when people move out, we won't charge you any rent.' I was a good mother but not an excellent one. I used to go to the pub a lot. I wish I'd been a better mother.

Anyway, I'm in Maroochydore and dad says to me, 'Beverly's getting out of jail.' She had ended up going in again because all the time she was whacked out on drugs. We drove down to Silverwater, in Sydney, and got Beverly out and she came back up and stopped with me in my unit. The police kept nagging us all the time. The police came and raided my house. They would rip my place apart. I put a complaint in about them and I was just told that I had an ex-convict living with me. I said, 'But that's not me! Why do that to my home?' 
I was fed up to the bloody neck with it. I was sick of it. So we moved to Caloundra. She had a unit and I had a unit. She was on the corner and I was back up a bit further. I was on the pension but I'd met somebody else who was helping me financially and my dad was there a lot, not that I was very fond of my father. Any man that doesn't come near his daughter until she's 18 , I don't think's a father's bum hole. He was an old drunk.

We packed up and moved to Bulimba and I had a big fight with Beverly. She up and went to Sydney and I followed her not long afterwards. I was working at Royal Doulton making hand basins and earning good money too and Michael was at school. My life centred around my child. I was with a bloke but I never married him. I'm not that stupid. Men are only useful as sperm banks. I met him up the pub when I was living near Beverly. On a Friday or Saturday night she'd say, 'Do you want to go out? I'll mind Michael.' We got a house in Chatswood. He was offered a job as a supervisor in a garbage company in Brisbane and he asked me if he bought a house would I move up there with him? I didn't know if I wanted to go that far because I didn't really want to be associated with a bloke again. I didn't have much time for them. He said if I come up to Queensland that I will never have to work another day. Within a month I had three jobs_cleaning jobs. Prick, he was. When I first moved here he put me in a caravan and I used to cry every day and say I was moving back to Sydney. We moved into the house I'm in now on Michael's tenth birthday. But we still live in the same house and that's since 1978. That's a lot, a lot of years. That's worse than a death sentence.

I had a heart attack in 1985 through all the stress that this prick has put me under. I was only 40 . He was playing up on me. If she had been anything to look at, I could understand but she was as ugly as a hatful of arses. Then he moved his mother in here and she used to shake up to me. She only come up to my shoulder and I'd say to her, 'Listen short arse, don't start with me cos I'll knock you into next week and your son will come next.' I told him, 'Either she goes or I go' and she went.

We live in the same house but we're not together anymore. In 2001, he hit me. We'd been drinking. The ambulance took me to hospital because my nose was spurting blood. The coppers took him away but they brought the bastard back. I had to go to court but I dropped the charges and he's never laid a hand on me since then. He knows better. I don't let any man put their hand on me. I say to them, 'Remember, you've always got to go to sleep!' He lives downstairs and I live upstairs. We talk but there's no 
intimate relationship. Michael thinks of him as his father. I made good money as a cleaner and getting other people to work with me. I was doing that until I was 69. Michael moved out three years ago and he's now 44. He was married but they split up. They've got a child. I get on all right with her and I dearly love my grandson.

Two years ago, I found out that I am Aboriginal. Gloria kept telling me and I said, 'Oh bullshit!' Then she sent me all the paperwork and I am now quite proud of the fact that I'm from one of the first owners of this land. Our grandmother, on my mother's side, was a native of New South Wales, a Kuringgai woman.

\section{The Forde Inquiry and Aftermath}

I started looking at my past when Leneen Forde opened the inquiry in 1998. I wrote a letter. I think Uniting Care were the first ones who came to us. I went back to Wolston Park to visit and they said, 'What are you doing here?' I said, 'Minding my own business. Why don't you try it sometime?' We were basically segregated from the Forde Inquiry. We went to one meeting where Peter Beattie announced compensation and they said that any women who went into Wolston Park were to go into another room.

By then I was starting to get really feisty and I said, 'Why are we being put in a separate room?' They told us that Wolston Park wasn't part of the Forde Inquiry. It seemed to be all done hushy-hushy.

There was one meeting in City Hall and they took me outside because I was going off my head. All the people who had been in institutions were sitting on the left-hand side and all the suits were sitting on the right-hand side. The women who had been in institutions were singing songs and I thought, 'How can you sing to these people as though nothing's happened?'

Beattie had a huge budget for this and I'm sure that some of this money went to pay for all these meetings with the suits-women dressed up to the nines with diamonds dripping off their hands. I think they were being paid to sit and listen to all the bullshit that they spoke. The people on the left looked like homeless people and I just thought about the difference between that side and the other side. Theyve got no idea what these people are going through and I just completely lost my temper. 
The people from Lotus Place came and got me and took me outside and I had a cigarette and they said, 'Let's go back inside', and I said, 'No. I'm going home. I'm not putting up with this bullshit.' I started to become outspoken. My blood pressure was out of control during the Forde Inquiry. I did receive a payout from the Queensland Government but that wasn't for being in Wolston Park but for being in the other institutions. I think the worst ones of the lot of them as far as having a bit of heart is the Salvation Army. I think they were bloody disgraceful. I really do. I tell you what, didn't I give them what for, too! I hated the Salvation Army. I hate them with a deep, abiding passion because they came through my house. There was two of them came through and a third one wanted to come through and I told him to bugger off, 'No, you're not coming through my house. I have enough of youse.'

They rang up my brother Chris who I did not have contact with for 29 years, but who's now come back into my life. He rang up the Children's Commissioner, 'What you did to my sister was an out-and-out disgrace'. We get on like a house on fire. We're as mad as two cut snakes. He's two years younger than me. He's a wealthy man but I don't ask anything of him and I don't expect anything of him. Any money that I've been given, I've invested it. His wife doesn't like me because of what I used to do for a living.

Beverly passed away in 2009, when she was 67, of chronic renal failure and hepatitis C. I loved Beverly. On my mirror, I've got a photo of her when she was a baby. She and I were so close but Beverly never had the strength that I've got. I don't smoke or drink because of my hepatitis. I got it off Beverly.

I never had a proper education because we were Home children. The teachers weren't interested in us but I was always very good at English. Mathematics, I'm hopeless at. I've been an avid reader. I read anything. I've got newspapers everywhere on my bed. The fact that we were denied an education is an absolute disgrace because I could be sitting in a highprofile job. I blame the Uniting Church for that. They didn't think then that girls should go on. 
Shithead Petersen didn't care. ${ }^{1}$ As far as he was concerned we were juvenile delinquents. He never stopped to think that maybe we were fed up with being institutionalised. I'd been in institutions ever since I was one and a half. I say, 'What if it happened to you or one of your children?'

Wolston Park affected me really badly. I'm embarrassed to say that I was placed in Wolston Park mental hospital. Immediately you say that you've been placed in a mental hospital people think, 'Oh, she must be mental'. I'm far from bloody mental. I'm only a nut when I see the funny side of life. I've got a damned good sense of humour but I don't take shit from no bastard. These people taught me to hate. They taught me to be one of the most persistent bitches that you've ever come across in your bloody life.

I'm still up in counselling through the Salvation Army and she's helping me a lot. I must admit that. I'm a very angry person but I'm trying not to be because the only person the anger hurts is me. I'm a really strong woman. I'm not full of shit. I never have been and I never will be. I don't like people who lie and I don't like people who bullshit. What you see with me is what you get and if you don't like it-stiff. And I will do everything, everything in my power to get a public hearing in the Royal Commission, but they don't care about us, do they? If I was younger, I'd buy a Winnebago and bugger off on my own.

1 Joh Bjleke-Petersen was the premier of Queensland from 1968-87. 
This text is taken from Goodna Girls: A History of Children in a Queensland Mental Asylum, by Adele Chynoweth, published 2020 by ANU Press, The Australian National University, Canberra, Australia.

doi.org/10.22459/GG.2020.03 